titles; a card index is issued free to members and can be bought by others. It consists mainly of films on pure and applied science, but no subject is ignored which is within the scope of a university. Medical films are also listed, but the Committee tries to avoid duplication of the work of the Film Committee of the British Medical Association and related organizations. Catalogues are, as a rule, easily accessible in university reference libraries, and many member institutions have as many as three copies in constant use. Index cards are $2 d$. each to nonmembers (minimum 5s.), and a revised list was published early in 1957. The Council also publishes the University Film Journal about three times a year, which contains relevant articles of interest to staff and students in universities, important reprints and as much news material from home and overseas as possible. At the time of writing, inquiries are being circulated throughout all member universities on the quality and kind of film needed by lecturers and professors, and what special film equipment is being held and would be available to colleagues.

The Council has successfully sponsored special conferences on the use of films in such diverse fields as modern languages (at the Institut français), arts subjects (at the Institute of Education, London), chemical engineering (at Birmingham), psychology (at University College, London); it has also, in the past, assisted in the selection of films for the annual British Association meetings.

\title{
UNIVERSITIES AND ADULT EDUCATION IN BRITAIN
}

\begin{abstract}
THE total number of courses conducted in Britain by university extra-mural departments during 1957-58 were rather fewer than during 1956-57, but still above the figure for 1955-56. Although this may give cause for modest satisfaction, the slight decline which took place was not evenly spread over the whole of the work but affected with disproportionate severity tutorial classes and residential courses, two branches of work which universities have traditionally cherished*. Since the beginning of the current decade the tendency has been for the number of tutorial classes to decline, but the sharp drop during 195758 is without recent precedent.

There are signs that the policy of financial limitation initiated a few years ago is now affecting extramural work, particularly in the type of course provided. In such work it is difficult to stand still; an attempt to curb developments inherent in the work is apt to lead to retrogression. Many extra-

* Universities Council for Adult Education. Report on the year 1957-1958. Pp. 28. (Bristol: W. E. Salt, Hon. Secretary and Treasurer, The University, 1959.)
\end{abstract}

mural departments were just able to hold their own, or reported small increases in the number of classes (usually shorter classes) in spite of grant problems.

At Glasgow it was reported that "during the past year some of the emergency cuts which had to be made, such as the reduction of the library grant, are likely to have a harmful effect on the quality of the work unless they can soon be restored". Nottingham had to reject ten requests from classes because of shortage of funds. At Oxford also there were financial problems. "The University Chest found itself forced to cut its grant for extra-mural work, with the result that the adult scholarship scheme was suspended and the number of classes fell more sharply than at any other university." The Delegacy for Extra-Mural Studies restated, in a memorandum submitted to the Hebdomadal Council, its firm belief in the value and importance of extra-mural studies, and "its regret that the work must be contracted at a time when the need for it had become even more urgent".

\section{THE CENTRAL AGRICULTURAL RESEARCH STATION, CARAPICHAIMA, TRINIDAD}

\author{
BY DR. A. J. VLITOS \\ Director
}

\begin{abstract}
7 HE new Central Agricultural Research Station located at Carapichaima, Trinidad, is an institution intended to foster fundamental and applied research relative to sugar cane. Supported by private funds (Caroni, Ltd., and Ste. Madeleine Sugar Co., Ltd.) the new Research Station is concerned with the agronomy, physiology, pathology, entomology, and biochemistry of sugar cane with the ultimate aim of applying in the field new information which may be forthcoming from the basic investigations.

The main section of the Station houses the physiology, pathology, entomology, and biochemistry units in an air-conditioned laboratory, fully equipped with the facilities required to carry out the research programmes. Adjacent to main laboratories are dark rooms and a temperature-controlled light room suitable for the growth of plants under controlled environmental conditions. A library, containing the pertinent scientific journals, is located in the east wing of the main building.
\end{abstract}

An agronomic programme, more applied in nature, will complement the fundamental studies in physiology. A major effort is being directed towards the control of froghopper (Aeneolamia varia saccharina) and the other major insect pests of cane in Trinidad. Chemical weed control, as well as new methods of cultivation, are also under investigation. Physiological and biochemical studies are concerned with the auxin relations in the developing cane seedling, from seed to flowering. In addition to the auxin studies, several investigations on mineral nutrition and photosynthetic efficiency will round out the physiology programme. The pathology programme is devoted to a thorough study of the rhizosphere of sugar cane, including a taxonomic investigation of the microflora and microfauna residing in the immediate vicinity of the root system, as well as an analysis of the interrelationships between the secretions of the root system and the microbial population. 